\title{
Humanities for Humanity
}

\author{
John Duncan
}

\begin{abstract}
AвSTRACT Since 2007, the Humanities for Humanity ("H4H") course has brought together student experience beyond the classroom, educational experiences for community members who could not otherwise attend university, discussion of social justice, and studies in the humanities. By discussing a selection of rich and influential primary texts from the humanities, course members are introduced to a rudimentary history of the present, focussing on who we have become as members of a concrete social and political reality intersected by capitalism, bureaucracy, liberalism, socialism, anti-essentialism, and post-colonialism. Both the texts and the student-participant encounters are rich, and the sessions are guided by two central classical ideals: the activity of learning is primarily an end in itself, and the most important thing to learn may be who we are. The core course content of $\mathrm{H} 4 \mathrm{H}$ is outlined, and the ways in which $\mathrm{H} 4 \mathrm{H}$ connects student mentors and community participants are discussed. Implications are drawn regarding what makes $\mathrm{H} 4 \mathrm{H}$ a unique form of community service-learning in which service is virtually eclipsed by learning in a process that subverts barriers between people.
\end{abstract}

KEYWORDS service-learning, humanities, social justice, outreach, self-understanding

This paper describes, and provides a preliminary analysis of, a community service-learning course in the humanities. The not-for-credit course, co-developed and directed by an academic - the author — and a dean of students, both with backgrounds in the humanities, has for over ten years maintained high demand and led to spin-off courses. The continuing demand and growth is taken to count as a strong prima facie measure of success: the course provides educational experiences that continue to be chosen both by undergraduate students, and by community participants who would not otherwise have the opportunity to attend university. The course's success is due in part to its content and the way the content is addressed, which include selections from so-called great books, themes in social justice, and ideals of inclusivity and the traditional humanities. Thus, the discussion here will include key aspects of both the core content of the course and its form. Next stages of analysis include the systematic collection of feedback from participants to enable analysis of their expressed evaluations with respect to specific aspects of the course. However, given its success, readers may find interest in a descriptive and preliminary analysis of this particular approach to humanitiesbased community service-learning. 


\section{Introducing " $\mathrm{H} 4 \mathrm{H}$ "}

During the fall term of 2007, Trinity College in the University of Toronto launched a course designed to bring together four desiderata: undergraduate experience beyond the classroom in the form of engagement with community members; a course experience for community members who would not otherwise have the opportunity to attend university; the discussion of social justice; and study in the humanities. A humanities course was offered to a mix of community participants and senior undergraduate mentors. The course was called Humanities for Humanity, soon nicknamed "H4H." The founding directors were the author, as director of the University of Toronto's Trinity-hosted major program in Ethics, Society, and Law, and Kelley Castle, then Dean of Students at Trinity, and later Dean of Students at Victoria College in the University of Toronto. To find community participants, we reached out to directors of local community centers who served disadvantaged people in the downtown Toronto area near the university. We imposed no specific criteria for eligibility beyond saying that the course was open to people who could not otherwise attend university and were intrigued by the idea of reading the proposed texts. Community participants and student mentors came together in the college one evening each week during the term to share meals, attend lectures, and discuss a selection of texts from renaissance Europe to contemporary Toronto. We covered the costs of the reading material, public transit, and a hot meal to begin each session, and student babysitters looked after the children of participants. We asked philosopher and critic Mark Kingwell to lecture on Machiavelli's Prince, and former Ontario Premier Bob Rae to lecture on Hobbes' Leviathan, to name a couple of the better-known contributors to the course. Lecturers, undergraduates, and community participants enjoyed themselves, and learned from each other and the texts. Everyone volunteered their time.

H4H has been offered annually since 2007. Since 2010, Trinity and Victoria have partnered to co-host it. The content and structure have remained mostly unchanged, but each year there is a new group of community participants and undergraduates. Demand-one important measure of success - has remained strong for a decade, leading to the development of cognate courses. In 2011-2012, Victoria launched a major umbrella program called Ideas for the World, under which it (1) manages its $\mathrm{H} 4 \mathrm{H}$ partnership with Trinity, (2) offers a new annual course similar to $\mathrm{H} 4 \mathrm{H}$ but devoted entirely to plays, called Theatre for Thought, and (3) offers a set of lunch-time co-curricular discussion series-some for undergraduates only, others for both undergraduates and community participants. Trinity has continued to be a full partner in H4H, and in 2013 launched H4H.2, a course based on the model of a reading group. H4H.2 is designed for community participants who have completed $\mathrm{H} 4 \mathrm{H}$ and Theatre for Thought and who want to continue the experience. Participants, undergraduates, and an instructor/ facilitator meet every two weeks to discuss books of interest. None of these offerings are for credit, but they keep filling and have been praised by participants and undergraduates alike, ${ }^{1}$ as well as by faculty. ${ }^{2}$

\footnotetext{
${ }^{1}$ Please see various accounts in the press and related media, which include participant and undergraduate learner voices: Brown, 2007; Loeb, 2007; Nayyar, 2007; Webb, 2008; Rupolo, 2013.

2 Please see Kingwell, 2017.
} 
$\mathrm{H} 4 \mathrm{H}$ involves community service, which, on the one hand, some consider to be an instance of charity. Thus, the course is about compassion - that is, about caring for "any who stand in need" (Acts 4:35, The New English Bible). Compassion is the primary meaning of the Medieval Latin "caritas," from which "charity" is derived. Out of compassion, one provides for those in need. However, charity is a charged term in the service-learning literature (see Tinkler, Hannah, Tinkler, \& Miller, 2014). Although we are not attached to the term, it is important to acknowledge that there is a relationship between what we do and charity. On the other hand, some consider $\mathrm{H} 4 \mathrm{H}$ to involve badly needed social resource redistribution-and in general we are guided by such ideas of social justice. However, although resources are gathered from those "according to ability" and distributed in the form of a course to those "according to need" (Marx, 1970), whether H4H fits into the service-learning category of charity or social justice is less important than its goals, as we will see below.

A group of undergraduate mentors facilitates the crucial discussion component of the course. Each mentor voluntarily undertakes this service for a term. Mentors are a group of co-learners with experience in the setting of a university course, and they are encouraged to facilitate discussion throughout each session. In this sense, mentors provide a service, from their abilities. However, as in many service-learning models, the service peculiar to $\mathrm{H} 4 \mathrm{H}$ is interwoven with mentor learning, and indeed mentor learning is one of the main goals of the course. Students receive no remuneration or academic credit for their participation. Despite the substantial commitment involved, students find the experience worthwhile, and often report that $\mathrm{H} 4 \mathrm{H}$ is one of the best experiences of their undergraduate careers. Interestingly, as I will argue in what follows, in service-learning of the kind being developed in $\mathrm{H} 4 \mathrm{H}$, what mentors learn from their service amounts to more than the sum of a set of learning outcomes.

Because $\mathrm{H} 4 \mathrm{H}$ is entirely voluntary, it has little beyond the experience of the course itself to maintain attendance. During the first couple of weeks of each course, the door is wide open, as it were, which helps attract not only participants who already have interests in books and ideas, but also those who have little idea that such things might interest them. All get to give the course a try to see if they can find a voice in it. The resulting range of participants who stay in the course more than compensates for the challenge of managing the variable numbers during the first couple of weeks. Accommodating students for whom the very idea of a university course is largely new is an instance of our general policy of broad inclusivity.

Typically, 20-25 community participants and 20-25 undergraduates finish the course. Meeting weekly for three-hour sessions that include a meal in common, a lecture, break-out discussions, and a discussion involving the whole group--and doing so with people who have the goal of explicitly establishing an open and friendly environment--generates cohesion well.

In the next section, I will outline the core course content of $\mathrm{H} 4 \mathrm{H}$ as a way to introduce its approach to the humanities and social justice. Then, in the succeeding section, I will indicate the ways in which $\mathrm{H} 4 \mathrm{H}$ connects undergraduates and community participants in a mutual learning experience, connecting university and community, and especially the ways in which such connections are beneficial to students and the academy. In the final section, I will pull out some implications of the service-learning being developed in $\mathrm{H} 4 \mathrm{H}$. 


\section{Course Content: Humanities and Social Justice}

In terms of content, the guiding vision of $\mathrm{H} 4 \mathrm{H}$ arises from a hybrid of traditional humanities and social justice. The overall goal is to provide a rudimentary history of the present, focused on main features of who we are (as individuals of concrete social and political realities). As Beauvoir (1989) argues, following Hegel, "to be" is "to have become" (p. xxx). Thus, we reach historically both as far back as is feasible, and forward to within a generation or so of ourselves, through a selection of rich and influential primary texts. We take each text on its own terms, exploring what makes it rich and influential, developing a historical sense of its context, and considering how it might be open to constructive criticism. Because the goal is to provide ways of discussing important aspects of who we have become, text selection is important; at the risk of being didactic, I will outline what has been central to our message in this regard.

Central to the beginning of the course is a selection (edited and translated by Collard, 1971) from the historian Bartolomé de las Casas' account of the European conquest of Caribbean "Indians" in the late fifteenth and early sixteenth centuries. Well-versed in the classics, and a captivating advocate for Indigenous peoples, Las Casas provides heart-wrenching reports and critical analyses of early modern colonialism. Members of Las Casas' family were involved in Columbus' journeys, and selections from his History provide a rich narrative of Spanish motives, colonial abuses, diplomatic struggles to protect Indigenous peoples, and campaigns of rebellion and conquest. Las Casas himself is a complicated figure. Witness to some of the worst practices of colonization, he was a one-time slave-owner who went through a radical conversion and then devoted himself to defending Indigenous peoples. He stood on the right side of history but not without imperfection. Las Casas tended to portray the Indigenous Taíno people of Hispaniola (now Haiti and the Dominican) as innocent lambs in contrast to the ravenous Spanish wolves who abused them. This illuminates major features both of what he took his mission to be, and of the context in which he worked, all of which allows us to discuss the challenges of historical writing and interpretation, as well as questions of voice. Thus, with Las Casas, the reader gets original accounts and criticisms of important aspects of the beginning of modern colonialism, which, of course, came to play a huge role in the development of who we are today. Each year many of the community participants have roots in former colonies, and Canada itself has a colonial history. Rather than select a text more directly related to the Canadian experience, Las Casas is read because his is the more canonical account of the beginning of modern Western colonialism, which in general grew out of the powerful countries of Europe to eventually reach around and change the history of the globe over the last 500 years.

Reading Las Casas makes clear an important point at the beginning of the course: that we discuss social injustice. Class members often raise comparisons and contrasts between the brutal exploitation on Hispaniola and examples of oppression in the world today, deepening perspectives regarding right and wrong in our world. Las Casas' history also lays a tangible foundation for later discussions in $\mathrm{H} 4 \mathrm{H}$, which trace colonization, decolonization, and neocolonialism down to our own time. 
Another text central to the beginning of the course is Thomas Hobbes' $(1651 / 1994)$ Leviathan (selections). Leviathan is a classic of liberal political philosophy. Hobbes stands out as an early enlightenment thinker whose political philosophy is ultimately grounded on the foundational idea of virtually all modern political philosophy - that political authority is legitimate only because individuals would choose it, and not for other reasons such as, for example, the divine right of kings. Wherever individuals end up being governed or managed by policies to which they would not consent, they have grounds for criticism and dissent. Consent, inextricably linked to liberty, must ground action in free-that is, liberal-society.

The idea of consent that grounds Leviathan still grounds relevant debates today, but certainly Leviathan is about more than consent, and about much that subsequent philosophers criticized. In effect, the foundation of Hobbes' state is liberal in that we would all choose it, but his sovereign ends up with the right to do whatever it thinks necessary to preserve itself, a right with which members of the $\mathrm{H} 4 \mathrm{H}$ class invariably express dissatisfaction. However, at least a few defend Hobbes' super-power sovereign on the grounds that it would be better than the instances of chaos they experienced in countries of origin undergoing widespread disorder. These newcomers to Canada have seen chaotic "states of nature," as Hobbes would call them, in which we might all very well consent to a powerful central authority in the first instance. The class ends up seeing the primary importance of security even as it is left with the idea that human rights, largely left out by Hobbes, must also be developed.

The next core text we read is Adam Smith's (1776/1993) Wealth of Nations (selections). Smith provides an account of modern commercial society-what we call capitalism. His explanations are equation-free, accessible, and interesting, famously detailing the division of labour, the fundamental human propensity to trade, the significance of self-interest in the market, and the basic tendency of markets to reach equilibrium. His account of the superior productive capacity of early modern capitalism's division of labour and market system is revealing, and upon close examination presents us with glimpses of both the inescapability of production's social nature and the political technologies of the body, which were to establish an important foundation for the industrial revolution then just getting underway. The world is broadly capitalist, as is our city (Toronto), and we (members of each H4H class) are deeply immersed in capitalism (whether we like it or not). These issues are raised through reading and discussing the work of capitalism's first great proponent.

We also read from Smith's history of the origin and development of European commercial society, in which he develops an account based neither on the deeds of great men, nor on an uncritical notion of progress, but rather on social and political conditions that arose after the fall of Rome and then developed during the medieval and renaissance periods. Smith helps us to see that capitalism has come into being. It is neither natural nor eternal, but rather something that might well have been otherwise, which opens up discursive space for engaged critical discussion.

Furthermore, Smith's history provides insight into the development of political institutions in Western Europe, and in so doing provides historical context directly relevant to what we look at in Hobbes and others. The social and political forces that developed during 
the medieval and renaissance periods contributed to the development of the institutions of modern political legitimacy. Thus, understanding Smith's history puts us in a better position to understand possible relationships between broad social and political forces and normative goals of our own time.

We read either Max Weber's (1922/2005) Economy and Society or Leo Tolstoy's (1886/1981) Death of Ivan Iyich to get a sense of the administrative nature of late modern mass society-a core idea in the course. While Weber's writings on bureaucracy provide the canonical account of this social and political type, in many ways Tolstoy's mini-novel provides an intimate critical view of it from the inside. In mass societies, if firms and states are to succeed, they need to integrate diverse offices - e.g., payroll, human resources, and primary business — within their overall operating systems. Bureaucratic organization is the management system that integrates offices- "bureaus" - in this way, and it comes with many features distinct from previous forms of management. When we work through Weber or Tolstoy, we think through examples of the necessarily bureaucratic provision of both public and private services in mass society to develop an understanding of the administrative form that pervades our world.

From Smith, we get a sense of the historical background and nature of our modern social and political formation as deeply capitalist; from Weber or Tolstoy, we get a sense of the same as deeply administrative. With Hobbes, we are introduced to the normative realm of legitimacy and the fundamental ideal of liberal — that is, free-society, which is the idea of consent, upon which so many aspirations have been based for more than three centuries. Each of these texts generates a conversation about deeply fundamental aspects of who we have become. In discussions, some want to transform capitalism, the administrative apparatus, or the individual-based legitimacy of liberalism, but others find themselves essentially grounded in and sympathetic to capitalism, bureaucracy, and liberalism. A major part of who each of us is has to do with the fact that as societies we have become capitalist, bureaucratic, and liberal, the understanding of which is no small part of understanding our world today.

We read Karl Marx and Friedrich Engels' (1848) Communist Manifesto to introduce the ages of revolution and socialist criticism and experiment that have had an immense impact upon the modern world. Marx and Engels, on the one hand, and Smith, on the other, work well together as they draw on similar historical accounts. At the same time, they are contraries in ways that continue to underpin core left-versus-right debates today. Thus, debates between those who think there is too much inequality in the world and those who think that inequality is a function of the efficient market with which we must not tamper unduly are debates that arise in our discussions of Smith and Marx and Engels. Who sides with Marx and Engels in these discussions, and who with Smith, is generally unpredictable.

We read selections from Simone de Beauvoir's (1949/1989) Second Sex to get a sense of modern feminism. Beauvoir's critique of the essential woman opens a door to the broader critique of essentialism that is an impetus for much of identity politics, a deeply important movement of our time. The critique leads into conversations about racialization, homophobia, and other kinds of "otherization." These conversations are robust and complicated, and thickened by an abundance of personal examples offered by both participants and undergraduates. 
We opened the important discussion of colonialism with Las Casas near the beginning of the course; it is picked up again when we read Frantz Fanon's classic engaged and critical discussion of decolonization toward the end. In Wretched of the Earth, Fanon (1963) provides a raw conversation about the point at which the violent marginalization of the colonized rebounds in the form of decolonizing violence. The great period of decolonization occurred in the middle decades of the $20^{\text {th }}$ century, and as Fanon so astutely anticipated, decolonization and its aftermath have been long and arduous. These processes, which began ultimately some 500 years ago, continue to affect the world in the $21^{\text {st }}$ century. For example, the Durand Line was drawn by the Imperial British between what became Afghanistan and Pakistan, which divided the massive Pashtun nation, the very birthplace and homeland of the Taliban, with whom NATO has fought its longest and perhaps most inconclusive war. ${ }^{3}$ The film Battle of Algiers (1966), a clip of which is often shown in $\mathrm{H} 4 \mathrm{H}$, and which became recommended viewing for Western military leaders in the $21^{\text {st }}$ century Global War on Terror, begun in Afghanistan, was directed by Gillo Pontecorvo, who was influenced by Fanon. As in the discussion of other core texts, $\mathrm{H} 4 \mathrm{H}$ students and participants find a great deal to say about all this. Many seem to recognize in Fanon echoes both of their own experiences, and of current events in the world. Not that Fanon's text says all there is to say about colonialism, but rather that it is a text to which many colonial cases and experiences can be fruitfully compared and contrasted. Indeed, this applies for all the texts in $\mathrm{H} 4 \mathrm{H}$, for although no single text can speak comprehensively for all the cases it can be used to address, when rich and influential primary texts are approached with informed, open and critical perspectives, they provide excellent points of departure for discussion.

Our final core text is Dionne Brand's (1997) novel In Another Place, Not Here, which resonates with many of the texts and ideas discussed throughout the course. Brand's novel boldly combines voices, dialects, and poetry and prose, as it weaves together recollections of the history of Caribbean slavery, the struggle for post-colonial social and political transformation, the difficult experiences of immigration and racial integration in late-modern Toronto, and delicate issues of gender, sexuality, and identity. Revolutionary struggle and Fanon are invoked explicitly, Beauvoir seems to offer a typology for the lead characters- two lesbiansand colonialism animates much of the novel's background. Some of our most candid and wrenching conversations have come out of the sessions on this text.

If not so long ago we became capitalists, bureaucrats, and liberals in important respects, we have also become revolutionaries, anti-essentialists, and post-colonials. These are deep features of who we are today as global citizens - features of our identity kept in sight throughout H4H. They ground the ways in which we develop the ongoing discussion of social justice. The aim is to treat each text on its own terms, and to bring it into dialogue with the other texts. As we come to see more clearly how we have become who we are, our discussions about justice find traction. For example, even if socialism appeals to us, capitalism surrounds us; alternatively, if socialism does not appeal to us, we shall nevertheless have to hear of it well into the future.

\footnotetext{
${ }^{3}$ Please see Duncan, 2016.
} 
This is the sense in which what may seem like a fairly traditional approach to the humanities, on the one hand, and a fairly indirect approach to social justice, on the other hand, come together in $\mathrm{H} 4 \mathrm{H}$. We do not read articles about social justice. Neither do we simply read the great books. We read a selection of rich and influential primary texts that traces how we have become who we are in late modern Toronto, and that includes not only the capitalist, bureaucrat, and liberal, but also the revolutionary, anti-essentialist and post-colonial global citizen. Thus, the course endeavours to intersect significant elements of what we have become. The content becomes the shifting ground for discussions carried on by the class itself. And discussion is the core of each session: preliminary discussion is encouraged during dinner (6:00-6:30 p.m.); the lecturer is asked to introduce the text and provide a few leading discussion questions (6:307:30); after a short break, intense discussion begins in breakout groups (7:40-8:20), followed by discussion in the whole group (8:20-9:00). Participants and students alike negotiate their responses to the texts and to each other in discussion, with the goal of better understanding ourselves and each other. Together, we discover ourselves as sites of contestation.

As we believed from the beginning, individuals from the community are excited to discuss Hobbes, Beauvoir, etc., because Hobbes and Beauvoir have things to say about what we have become. Central to our approach is the idea that reading and discussing each text is an end in itself. We read Hobbes in order to read Hobbes, not in order to set hurdles for Rousseau, pass tests, or pick up skills. Behind this view is a classical idea of the humanities, that learning as such is its own reward. We read Hobbes, and each of the rest, not as a means to some end, but rather as an end-in-itself. We have adopted this idea because learning is deeply embedded in human life, so much so that it is tempting to follow the ancients when they argue that the capacities of learning and intellectual thought are the distinguishing features of being human. Our readings are moments in the legacy of human self-interpretation. We participate in this legacy-conversation in the twenty-first century, not to solve any particular problems, but to understand.

Certainly, $\mathrm{H} 4 \mathrm{H}$ is inspired by the idea of outreach. Another motive arises from the idea that diverse voices are fundamentally important to our own understanding within the academy, the issue to which I turn in the next section.

\section{Student-Participant Engagement: Opening the University}

One interesting theme in Tolstoy's (1886/1981) Death of Ivan Iyich is that we can lose interest in diverse voices, or perhaps not have that interest to begin with. Tolstoy's Ivan Ilyich has no time for what does not fit into his idea of the proper life. He never turns to others to listen to them. Not his own circle of friends - not even his family-and certainly not any of the individuals who appear before him in court. Ivan is interested in his prosperity, prestige, and proper pleasures. Anything that deviates from those interests is something to be avoided. Only when Ivan is forced to face the unexpected approach of his own death do the stories he has told himself for so long begin to unravel. All-too-often we find ourselves within careers, etc., which bear similarities to Ivan's path. Essential to $\mathrm{H} 4 \mathrm{H}$ is the idea that being genuinely open to others — although it requires time and effort—is a good thing. 
When we have discussed Las Casas' accounts of the European slaughter of Indigenous peoples, we have had among our discussants people from refugee communities who have lived through much more recent tragedies in places such as Syria, Algeria, Rwanda, and Congo. Their comments — and their very presence- - have disrupted what might otherwise have been merely academic conversations. We could not look them in the face and say something merely theoretical or pass along facts or statistics heard second-hand about colonialism, exploitation, or racism, at least not without feeling we had to be careful — that is, not without feeling we had to care about what we were saying. The faces across the table-into which we were lookinghad themselves looked such things in the face. For the undergraduates, all of a sudden, talking about the assigned material no longer had to do with participation grades or trying to score well on upcoming assignments; the discussion had to do with what the text was about, e.g., the real issue of violent exploitation.

I am reminded of Borges' poem “The Other Tiger.” In a long first verse, Borges portrays a wonderfully life-like tiger in the morning jungle. We are drawn into the jungle, to the tiger itself. But then, the second verse:

Afternoon creeps in my spirit and I keep thinking

that the tiger I am conjuring in my poem

is a tiger made of symbols and of shadows,

a sequence of prosodic measures,

scraps remembered from encyclopaedias.

Borges goes on to contrast this conjured tiger with the real tiger it is not. It is not

[...] the deadly tiger, the luckless jewel

which in the sun or the deceptive moonlight

follows its paths, in Bengal or Sumatra,

of love, of indolence, of dying.

As readers, we understand that the first tiger was conjured, but in making the conjuring itself explicit, Borges turns us away from it, toward the real tiger.

Against the symbolic tiger, I have planted

the real one, it whose blood runs hotly,

and today $[\ldots]$

a slow shadow spreads across the prairie.

"[S]till," even as we are turned toward the real tiger,

[...] the act of naming it, of guessing

what is its nature and its circumstances

creates a fiction, not a living creature,

not one of those who wander on the earth. (1967, p. 81-82) 
Borges reveals how easily we are deceived by word on paper. In his poem, the word itself turns us away from the paper-toward the prairie — and we think we glimpse the real tiger at last, but it is yet another paper tiger.

Of course, in academia it is in words, and in theoretical words, that "we live and move and have our being," to borrow one of the early Hegel's favourite biblical passages (Acts 17:28, The New English Bible). Because of this, academics may slide into posturing more easily and more willingly than Dante's Paulo and Francesca fell into their barely willed embrace. Paulo and Francesca were overcome by desire for each other, which in itself is a natural, good, and formidable force, but their kiss constituted a violation of Francesca's marriage to Paulo's brother. Failing to steel themselves against the pull of desire, they slipped into a transgression. Although I am suggesting that falling into academic posturing is analogous to succumbing to desire, in fact the former may be driven by intellect and so it may be a much more voluntary and therefore a much more serious transgression according to Dante and his authorities (who were Thomas and Aristotle), creating a much deeper hell for those who choose it.

"Back to the things themselves" was the rallying cry of phenomenology. It signified both the importance of careful descriptions of things as they are experienced, and the danger of analyses based on theoretical beginnings. The academy needs to be vigilant and work against the tendency to begin and carry on with theories about things rather than with the things themselves. Levinas drank from the cup of phenomenology and explored the "face-to-face" encounter. "First philosophy," he argued, properly begins with the face-to-face and it always already involves ethical possibilities. Being face-to-face with another person, my attempts to provide a theoretical account are repeatedly open to disruption. When non-academics, members of the community, many of whom are objects of our theories in one way or another, are invited into the discussion, our fall into posturing is disrupted. One reason for the disruption is that the community is not familiar with the forms of statement that function as various moves in the games of academic discourse (in which we live and move and have our being), so that academically adequate and impressive moves fall on deaf ears. ${ }^{4}$ Of necessity, we must address the member of the community on their terms, or the discussion remains fakepossibly silencing. If we are compassionate, we feel compelled to drop our posturing-we might even feel embarrassed by it. We ought to first find out what the other is saying, and then begin the discussion from there.

A few times, when we have discussed Marx and Engels in $\mathrm{H} 4 \mathrm{H}$, the discussion has turned into debate, and sometimes the debate has become heated, and we have had to think quickly to keep it civil. Some of our discussants have lived through classism in its worst forms in this country and they have intense-disruptive_-views about it. The results have been similar when we have discussed other texts.

Each year, half a dozen or so class members volunteer to say a few words during the final, celebratory session. Participants and undergraduates repeatedly say that what they have learned from their involvement in $\mathrm{H} 4 \mathrm{H}$ has been irreplaceable. For undergraduates, not so

${ }^{4}$ Please see Foucault's methodological analysis of the specific regularity of each discursive formation he examines in intellectual history.

Engaged Scholar Journal: Community-Engaged Research, Teaching, and Learning 
much the texts and lectures, but rather the community participants' engagement with the material has been especially important. $\mathrm{H} 4 \mathrm{H}$, they say, is no longer just another course of readings in stuff that might be interesting if one were not being forced to wiggle through four other such courses of readings at the same time in a competition for grades, itself part of a more challenging competition for places in the machinery of late modern capitalism and administration. The participants are not academic models. They are some of the real people most impacted by such models. They have experience-based things to say that bring unexpected reverberation to talk about the models. The sessions are eye-opening and they allow each of us briefly to get out of ourselves, to get to know others, and to get to know ourselves through others, advancing one of the explicit goals of the course- to know ourselves.

"Know thyself" is perhaps the most famous saying of the Oracle of Delphi-we ought to understand who we are. In $\mathrm{H} 4 \mathrm{H}$, seeking to know who we are as participants, mentors, faculty, and citizens of twenty-first century Toronto, together we discuss primary texts that express the realities that have made us who we have become.

It was as a university student that Tolstoy's Ivan Ilyich "had become exactly what he was to remain the rest of his life: a ... man ... strict to carry out whatever he considered his duty" (p. 50). Tolstoy's portrayal of Ivan brings out how we almost inevitably conform to and reproduce the prevailing apparatus of power and in-so-doing shut down other possible lives. Tolstoy seems to worry that we are living in order to work — not because we might be workaholics, but rather because the choices and behaviours required to maintain careers with status can eclipse life. Tolstoy's judgment is that "Ivan Ilych's life had been most simple and commonplace" (p. 49). Indeed, we all conform quite naturally, but, Tolstoy adds, the utterly commonplace life is "most horrifying" (p. 49). Opening the door to real diversity during undergraduate education is one small way to contribute to avoiding the horror. Because each $\mathrm{H} 4 \mathrm{H}$ course strives for both openness to diversity and stand-alone holistic status, it might avoid becoming commonplace.

Openness to diversity invites disruption into the academy, which reminds us that the perspectives we have on the real world mediated through academic work are not necessarily the same thing as the real world. ${ }^{5}$ Being an end in itself-i.e., standing alone as a holistic experience- $-\mathrm{H} 4 \mathrm{H}$ resists being a mere means to other ends. Thus, both as a disruptive reminder and as resistance to mere instrumentality, $\mathrm{H} 4 \mathrm{H}$ escapes the fate of so much in our hyper-specialized results-driven late modern world.

A text we often read during the week of Halloween is Mary Shelley's Frankenstein. If a novel is a kind of letter from the author to the reader, Frankenstein (itself an epistolary novel) is a letter that reveals to us the monstrosity of life without love. ${ }^{6}$ For readers who are like Shelley's character Walton, the novel can reveal the importance of love in a world that often seems to be eclipsed by money, power and spin. Indeed, in such a world, where the lives of many are frequently violated, returning to Shelley's meditation on the fundamental value of love would seem worthwhile. Caring for each other is at the heart of $\mathrm{H} 4 \mathrm{H}$. The discussion of charity

\footnotetext{
${ }^{5}$ Please see my related meditation on "the real": Duncan, 2013.

${ }^{6}$ So I argue: Duncan, 2011.
} 
above is relevant here, but openness to diversity as compassion is not merely charity. Rather it is the ground for a form of engagement that seeks to open itself to people of divergent perspectives in ways that exceed stipulated learning outcomes. $\mathrm{H} 4 \mathrm{H}$ is not primarily aiming for learning outcomes in either social justice or humanities education; rather the humanities and social justice are crucially important sites of interaction regarding big questions that circle around who we are. Paradoxically, this sort of engagement, which some might argue confuses charity and social justice, hears echoes of itself, at least in part, in attempts to nudge social justice service-learning from well-developed theory to better real-world engagement (e.g., Butin, 2015).

\section{Humanities and Engagement}

$\mathrm{H} 4 \mathrm{H}$ provides the opportunity for learning as an end-in-itself, a seemingly simple thing. However, what seems simple is not always easy to achieve. Consider the following classical passage from Heraclides Ponticus, who tells the story of a ruler named Leon who was very impressed by Pythagoras and asked him about his profession. Pythagoras said he was a "philosopher":

This word was strange to Leon, and, to explain to him what it meant, Pythagoras
employed a simile... Life, he said, is like the gathering at the Olympic festival, to
which people flock from three motives: to compete for the glory of a crown, to buy
and sell, or simply as spectators. So in life ... some enter the service of fame and
others of money, but the best choice is that of those few who spend their time in the
contemplation of nature, as lovers of wisdom, that is, philosophers. (Guthrie, 1962,
p. 164)

By providing a setting in which competition for status ("fame") and the necessity to work ("money") are temporarily bracketed, $\mathrm{H} 4 \mathrm{H}$ allows students and participants "to look on," theörein in classical Greek (to be a spectator, to observe or contemplate), a word at the root of the English "theory." To theorize in this sense is to step back from the realms of competition and necessity in order to observe, contemplate, and discuss the affairs of life-not to be wholly caught up in them-which is to participate in the philosophical life. The ideal philosophical education, as sketched by Plato, reaches its summit with the contemplation of the order of all things. If one were provided with the "leisure" to step back from competition and necessity in order to be properly "schooled" (a word descended from the classical Greek "schole," meaning "leisure") in the order of all things, one might attain the very summit. Because we must suffer reality wherever we act in ignorance of it, for Plato, comprehension of reality was ultimately "splendid," purely "beautiful," utterly "good" — an end in itself, not a means to a further end (Plato, 1961, Symposium 211c and Republic 508d-509c). In H4H, as in Plato, we are provided with opportunities to bracket the realms of competition and necessity in order to contemplate reality together. Main features of our social and political identities-e.g., capitalist and socialist, liberal and revolutionary_are discussed in so many feasts of reason, bringing

Engaged Scholar Journal: Community-Engaged Research, Teaching, and Learning 
each of us closer to our reality, from the perspective of which we might avoid suffering and live more fully.

In contrast to the goals of $\mathrm{H} 4 \mathrm{H}$, service-learning research in Canada tends to be focused on much more specific goals, often circulating near the notion of developing social justice conceptions of citizenship (King, 2006). For example, VanWynsberghe and Andruske (2007) utilized service-learning in a first-year sociology course in which service was required and in which reports of student engagement were collected and analysed with respect to Nancy Fraser's conceptualization of the public sphere. That is, VanWynsberghe and Andruske were looking for very specific outcomes. They concluded: "We have illustrated how community service learning can introduce students to their roles as engaged citizens” (p. 371). These are laudable goals, but they are not the goals of $\mathrm{H} 4 \mathrm{H}$. At least two things need to be said about this.

First, our goals in $\mathrm{H} 4 \mathrm{H}$ are far less specific. We bring the academy and the community together in order to discuss great humanities texts and social justice, and in so doing we are guided by two central classical ideals: the activity of learning is primarily an end in itself, not merely a means to some other end, and the most important thing to learn may be who or what one is (as an individual of a particular social and political reality). All of this is indeed pretty indeterminate when contrasted with paradigms of specific learning outcomes, for which see Gemmel and Clayton (2009) for example, but because we know that both the texts and the university-community encounters are deeply rich, we are neither concerned with fully anticipating, nor could we fully anticipate, specific outcomes. Framing $\mathrm{H} 4 \mathrm{H}$ with this kind of openness, in which we discuss what we have become, including within it fellowship and meals, and maintaining it as an end in itself, all help to constitute it as something of a stand-alone holistic experience. Each part helps to co-constitute it as something greater than the sum of its parts, so that as the whole develops each year, students and participants find themselves fitting into a place that enables them to question and express themselves together. As long as they continue to do so, the course will have a reason for being.

Second, although we certainly discuss it, engaged citizenship has not been a guiding concept. We end the course with a text that brings many of the course themes home to our own city, but the goal is not primarily to become better citizens of Toronto. Rather, it is to understand something about who we are as Torontonians. The implications of this for citizenship in Toronto are likely good. Nevertheless, if self-understanding is good for citizenship, we do not work toward it for that reason. We work toward it because it is good as such.

In this vein, it is worth considering $\mathrm{H} 4 \mathrm{H}$ in comparison with Earl Shorris' well-known Clemente Course, which has inspired other excellent humanities-based service-learning courses in Canada. ${ }^{7}$ According to Shorris, the Clemente Course aims to provide a humanities education to the poor in order to help them deal with poverty. The humanities provide excellent experiences of learning in thinking, understanding, criticism, and expression, which empower personal agency, which itself facilitates political agency-i.e., agency with respect to

\footnotetext{
${ }^{7}$ For a discussion of relevant Canadian courses please see Klassen, 2013.
} 
one's community. And political agency in this sense is necessary for avoiding the worst traps that come with poverty (Shorris, 1997). In H4H, if self-understanding is good for political agency, we do not work toward it for that reason. We work toward it because it is good as such.

None of this is to say that citizenship, personal agency, or political agency are goals not worth pursuing - not at all. Neither is it to say that such goals do not flow, at least in part, from self-understanding-far from it. Rather, it is to say that self-understanding is a goal worth pursing for its own sake.

Finally, it is important to think carefully about the concept of service. The college students in $\mathrm{H} 4 \mathrm{H}$ tell us that they feel they have received more than they have given during the course. There are a number of ways to account for this, but one way in particular is worth considering in this context. It is often said that when students engage in community service, not only do they contribute to the community, but they also learn from their service. For this reason, community service-learning is an important part of the Canadian academic landscape. ${ }^{8}$ However, in this formulation of service-learning, the service logically comes before the learning. In $\mathrm{H} 4 \mathrm{H}$, the priority of service is much reduced. Student mentors provide a service in helping to facilitate discussions, but mentors are asked to facilitate only as much as is required to encourage participants to discuss the material. In this way, the service component is minimized and the listening component is maximized (for the students). The virtual eclipse of service by listening in this service-learning model is in fact part of the very process of engagement that subverts barriers between people. As such, it is a prerequisite for any genuine relationship of service as gift. Moving toward that prerequisite is at the heart of $\mathrm{H} 4 \mathrm{H}$.

$\mathrm{H} 4 \mathrm{H}$ is a course - a service to be sure-delivered in part to community participants who could not otherwise attend university. However, its mode of delivery essentially depends upon the receptive agency — rather than the receptive passivity_of the community members. We seek to make each session a gift_ — rooted neither in paternalism nor exchange- that amounts to the opportunity to freely discuss and think together about who we are.

We might be able to glimpse ourselves in a clearer light if (a) community participants are provided with the opportunity to engage (if competition and necessity are temporarily suspended), if (b) we academics are fortunate and attentive enough to suspend our careerserving machinations and open ourselves to the voices of others, and if (c) together we attend carefully to great texts that help us understand who we have become.

\footnotetext{
${ }^{8}$ For indications of its development please see King (2006) and Gemmel and Clayton (2009).
} 


\section{About the Author}

John Duncan is director of the Ethics, Society, and Law program at Trinity College, and academic director of Victoria College's Ideas for the World program, in the University of Toronto. He has published in the humanities, philosophy, peace and conflict studies, and politics. Email: jduncan@trinity.utoronto.ca

\section{References}

Beauvoir, S. (1989). The second sex. (H. M. Parshley, Trans.). New York, NY: Vintage Books. (Original work published 1949).

Borges, J. L. (1967). The other tiger. In A. Kerrigan (Ed.), A personal anthology (pp. XXX). New York, NY: Grove Press.

Brand, D. (1997). In another place, Not here. Toronto, ON: Vintage Canada.

Brown, L. (2007, December 31). Poverty-stricken offered glimpse of academic life. Toronto Star.

Butin, D. (2015). Dreaming of justice: Critical service-learning and the need to wake up. Theory Into Practice, 54, 5-10.

Dante. (1962). The divine comedy 1: Hell. (D. L. Sayers, Trans.). Harmondsworth, Mddx.: Penguin Books.

Duncan, J. (Summer 2011). Frankenstein's message: Life without love is monstrous. First Light: The Biannual Publication of the Canadian Centre for Victims of Torture, 24-27.

Duncan, J. (2013). Descent to the things themselves: The virtue of dissent. In K. Hermberg \& P. Gyllenhammer (Eds.), Phenomenology and virtue ethics. London, England: Bloomsbury.

Duncan, J. (2016, July 26). The war that never left Afghanistan. OpenCanada.

Fanon, F. (1963). The wretched of the Earth. (R. Philcox, Trans.). New York, NY: Grove Press.

Foucault, M. (1972). The archaeology of knowledge. (A.M. Sheridan Smith, Trans.). New York, NY: Pantheon Books.

Gemmel, L. J., \& Clayton, P. H. (2009). A comprehensive framework for community service-learning in Canada. Guthrie, W. K. C. (1962). A bistory of Greek philosophy: Volume I. Cambridge, England: Cambridge University Press.

Hobbes, T. (1994). Leviathan. E. Curley (Ed.). Cambridge, England: Hackett. (Original work published 1651)

King, C. (Ed.). (2006). Community service-learning in Canada: A scan of the field.

Kingwell, M. (2017). A populist wake-up call for universities. Academic Matters.

Klassen, J. L. (2013). Taking up space: A case study exploration of the relationship between citizenship and free Humanities programs in Canada. Theses and Dissertations (Comprehensive). 1620.

Las Casas, B. de. (1971). History of the Indies. (A. M. Collard, Ed. and Trans.). New York, NY: Harper and Row.

Levinas, E. (1969). Totality and infinity. (A. Lingis, Trans.). Pittsburgh, PA: Duquesne University Press. 
Loeb, J. (November 2007). Inspiration at Humanities for Humanity. Sal Terrae, 19-20.

Marullo, S., \& Edwards, B. (2000). From charity to justice: The potential of university-community collaboration for social change. American Behavioral Scientist, 43(5), 895-912.

Marx, K., \& Engels, F. (1848). The communist manifesto. F. Engels (Ed.). New York, NY: International Publishers.

Marx, K., \& Engels, F. (1970) Critique of the Gotha programme, Part I. Moscow, Russia: Progress Publishers.

Mitchell, T. D. (2008). Traditional vs. critical service-learning: Engaging the literature to differentiate two models. Michigan Journal of Community Service Learning, 14(2), 50-65.

Nayyar, A. (2007, December 11). Trinity course brings out students' humanity. University of Toronto Bulletin, 7.

Plato. (1961). The collected dialogues of Plato. (E. Hamilton \& H. Cairns, Trans.). Princeton, NJ: Princeton University Press.

Pontecorvo, Gillo. (1966). The Battle of Algiers. Casbah Films.

Rupolo, D. (2013, April 6). The ivory tower [Video file].

Shelley, M. (1993). Frankenstein. New York, NY: Oxford University Press. (Original work published 1818)

Shorris, E. (September 1997). On the uses of a liberal education as a weapon in the hands of the restless poor. Harper's Magazine, 50-59.

Smith, A. (1993). The wealth of nations. K. Sutherland (Ed.). New York, NY: Oxford University Press. (Original work published 1776)

Tinkler, B., Hannah, C. L., Tinkler, A., \& Miller, E. (2014). Analyzing a service-learning experience using a social justice lens. Teaching Education, 25(1), 82-98.

Tolstoy, L. (1981). The death of Ivan Ilyich. (L. Solotaroff, Trans.). Toronto, ON: Bantam Books. (Original work published 1886)

Vanwynsberghe, R, \& Andruske, C. L. (2007). Research in the service of co-learning.Canadian Journal of Education, 30(1), 349-376.

Webb, M. (Spring 2008). Freedom. Trinity Alumni Magazine, 32-34.

Weber, M. (2005). Readings and commentary on Modernity. S. Kalberg (Ed.). Malden, MA: Blackwell Publishing. 